\title{
Molecular aspects of $\mathrm{sGC}$ regulation
}

\author{
Michael A Marletta*, Eric S Underbakke, Nathaniel B Fernhoff \\ From 5th International Conference on cGMP: Generators, Effectors and Therapeutic Implications \\ Halle, Germany. 24-26 June 2011
}

Mammalian sGC is a heterodimer composed of $\alpha$ - and $\beta$-subunits (Figure 1) [1]. The C-terminus of each subunit contains a catalytic domain, and the active site is composed of residues from both subunits. Sequence analysis shows that each subunit also contains a welldefined PAS-like domain, and a predicted helical region. The $\mathrm{N}$-termini of the $\alpha$ - and $\beta$-subunits are homologous to the H-NOX ( gen) family of proteins. The $\overline{\mathrm{N}}$-terminus of $\beta$-subunit contains a ferrous heme cofactor that serves a receptor for NO.

Ferric heme oxidized sGC has low activity, and the NO complex of the re-reduced heme generates a desensitized, low-activity state of sGC. The molecular mechanism for this desensitization involves site specific S-nitrosation. The conformational changes associated with activation are both subtle and complex. Hydrogen-deuterium exchange mass spectrometry analysis can be used to probe conformational changes and protein-protein interactions. This method has been brought to bear on sGC, illuminating domain interactions within sGC and conformational changes induced by NO binding.

Published: 1 August 2011

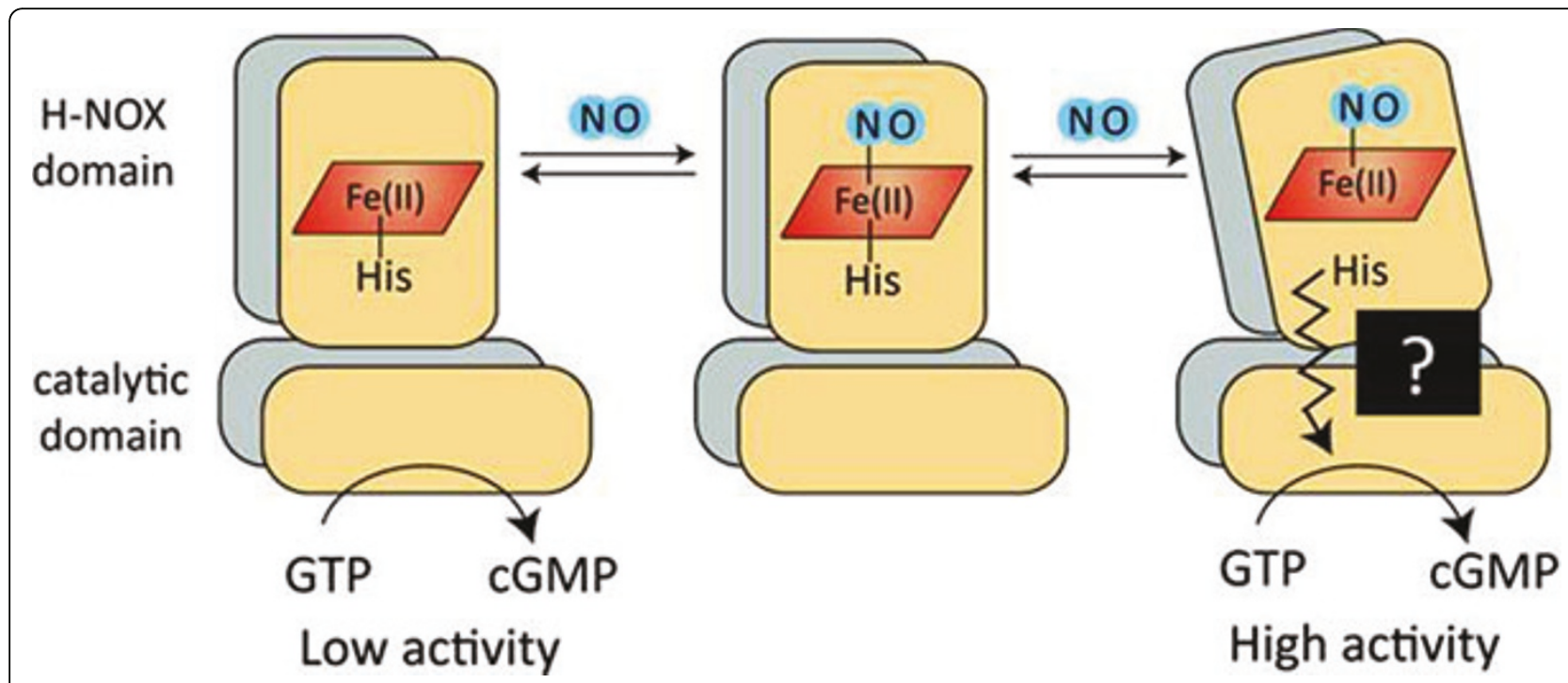

Figure 1 Schematic of SGC regulation by NO. In the resting, unliganded state, sGC has a low basal activity. The addition of NO leads initially to a 6-coordinate complex that then forms a highly active 5-coordinate complex. Evidence supports an additional requirement for NO that accelerates the formation of the 5-coordinate complex and fully activates the enzyme.

* Correspondence: marletta@berkeley.edu

University of California, Berkeley, Berkeley, CA 94720-3220, USA

(c) 2011 Marletta et al; licensee BioMed Central Ltd. This is an open access article distributed under the terms of the Creative Commons 


\section{Reference}

1. Derbyshire ER, Marletta MA: Biochemistry of soluble guanylate cyclase. Handb Exp Pharmacol 2009, 191:17-31.

doi:10.1186/1471-2210-11-S1-010

Cite this article as: Marletta et al:: Molecular aspects of sGC regulation. BMC Pharmacology 2011 11(Suppl 1):010.

Submit your next manuscript to BioMed Central and take full advantage of:

- Convenient online submission

- Thorough peer review

- No space constraints or color figure charges

- Immediate publication on acceptance

- Inclusion in PubMed, CAS, Scopus and Google Scholar

- Research which is freely available for redistribution 